\title{
SWOT Analysis on Inclusive Education in Indonesia
}

\author{
Ichsan Anshory \\ University of Muhammadiyah Malang \\ ichsananshory@yahoo.co.id
}

\begin{abstract}
Inclusive education occurs when the children with and without disabilities participate and learn together in the same classes. This study was a literature-based research which seeks relevant theories to the cases or problems found. The references obtained by way of literature-based research served as the basis of data retrieval. The SWOT Analysis of the implementation of inclusion in Indonesia is as follows. Inclusive education in Indonesia can enable children with special needs to learn more independently and to be directed with normal children (Strengths). Further, various children with disabilities require different guidance and assistance in terms of curriculum, lesson plans, media, and assessment (Weaknesses). The inclusive education programs in Indonesia are supported by the government so that the special law and regulations are issued for the implementation of inclusive education. It affects to the mental and psychological side of children with special needs that can build up well because they are incorporated with the normal children (Opportunities). Finally, the government and the schools of inclusive education providers should be able to improve the service, effectiveness, and efficiency of inclusive education (Threats).
\end{abstract}

Keywords: SWOT Analysis, Inclusive

\section{INTRODUCTION}

Education is a basic matter which is needed by each human being intended to assure his/her life sustainability. State has an obligation to provide educational services to each citizen without any discrimination either to normal children or children with special needs. In the Law No. 20 year of 2005 regarding the National Education System, it is stipulated that the state provides education for children with special needs or with abnormalities. It is stated in Verses 15 and 32 on Special Education that special education is education intended for students with abnormalities or those with great intelligences inclusively at school level. [1]. Inclusive education is another name for education but it employs a different approach to identification and solution of problems and difficulties at schools. Inclusive education in Indonesia itself is the government policy intended to widen educational services to children with special needs using a curriculum which is adapted to types of disabilities. Moreover, it is one of the educational dimensions that gives a priority to the quality and are rights-based. This type of education adopts a child-centered education system [2].

At first, this education in Indonesia was intended to serve children with special needs where the government established special schools for them, known as Sekolah Luar Biasa (SLB) (Extraordinary School). However, this kind of school turned out building a wall for the children with special needs since there is a separation between the children with special needs and normal children. Therefore, the government wants improve the educational system in Indonesia by treating the children with special needs and normal children equally through inclusive schools. It is through the establishment of such an educational system that children with special needs may study together with normal children.

Inclusive education is a solution to the difficulties the children with special needs face in getting educational services completely [3]. Inclusive education views the daily life realities and accepts that each child is different or diverse, and the statement of normal or abnormal merely refers to one or some of the aspects of a whole. It means that inclusive education is the combination of extraordinary and regular education in an educational system unified by an inclusive education system where the classification of "normal" and "abnormal" is abolished. There are some aspects that should be mastered or should exist in a school adopting an inclusion-based education, namely [4]: (1) the school, (2) grouping students according to the types of needs, 3) school placement, 4) infrastructures and facilities, 5) teachers, 6) learning activities, 7) after graduation, 8) the government's efforts. In the implementation of inclusive education, there has been incompatibility between the school and the government as the initiator of the inclusion-based school that causes the process of the inclusive education not to run maximally. It is a pity that a good initiation of an inclusive education cannot be applied in the field; the school cannot implement this inclusive education well in line with the intention of the government as stated in the specific guidance for the implementation of inclusive education : to realize an education without any differences or discriminations.

In Indonesia, the characteristics of inclusive education are as follows [5]: 1) relationship is established in a friendly and warm way, 2) teachers' and students' abilities and backgrounds are different from those of the parents as the assistants, 3) seating 
arrangements are made for all subjects, 4) learning materials are from various sources for all subjects, 5) teachers' daily plans are made by involving students so that they will be interested in studying, and 6) in the evaluation process, the children with special needs have its own specific standards in line with the individual. Important components [6] in establishing inclusive education are as follows. 1) Normal children and children with special needs are joined. 2) Before the children with special needs enter the school, a specific classification should be made to recognize and classify aspects of their potential, competences and characteristics to determine the education or intervention programs intended to develop all potentials they possess. Moreover, assessment is also beneficial for knowing their learning superiority and hindrances, so that the programs made will be in line with them. 3) The academic curriculum adopted by the operator of inclusive education is the school-based curriculum which is able to accommodate the intelligence, talent, interest and potential of the students with special needs, so that, a curriculum special for self-building is employed. 4) Inclusive education fosters the communication of the students with disabilities. 5) It procures and manages teaching aids. And 6) it develops integrated educational programs sustainably.

In the inclusive education in Indonesia, not all children with special needs may be able to study with normal children. The classification of children with special needs that may be joined with normal students are as follows (7) : 1) children with light impaired vision, 2) slow learners with the IQ level of 70, 3) children with physical or health impairment, 4) children with learning difficulties, 5) slow learners, 6) children with excellent abilities, 7) children with communication impairment.

There are still some strengths and weaknesses of the inclusive education in Indonesia. The different characteristics of children with special needs should be solved. One of the hindrances is their socialization aspect. The strengths and weaknesses will be described through the SWOT analysis. SWOT analysis (8) is a model of the identification of various problems systematically so that the problems may be solved. This SWOT analysis is based on the events in the field and the sources of theories that may maximize the strengths and opportunities and minimize the weaknesses and threats.

\section{METHOD}

It was a literature study by looking for various references and theories with relevant cases. References and theories which were relevant with the problems studied serve as the main foundation for problem solving. The data obtained by the researcher were analyzed using a descriptive analysis method. This method was made by describing anything found and analyzed. Therefore, it did not merely describe but also gave some understandings with explanations in line with references and theories.
This present research used the primary data by making observations and the secondary data obtained from journals, books, and the internet. The data obtained were then descriptively analyzed. The descriptive analysis method was made by describing facts which were then followed by an analysis; but the analysis was not made directly, it rather gave some understandings and explanations as necessary.

\section{RESULTS}

Inclusive education is an education that does not specialize in children with special needs, but the one that accommodates children with special needs and normal children to be able to study together in the same room. Therefore, inclusive education is the place for children with light to moderate disabilities in the class. This shows that a regular class is a relevant learning place for children with disabilities. Inclusive education reflects education for all without any exception such as those with social and physical limitations. The implementation of inclusive education also has weaknesses and opportunities as stated in the SWOT analysis. The analysis of the implementation of inclusive education covers strengths, weaknesses, opportunities and threats.

\section{Strengths}

The strengths of the implementation of inclusive education in Indonesia that is classified into an internal system are as follows:

1. Equal rights and obligations are unlimited and the discrimination in education in Indonesia between children with special needs/inclusive children and normal children still exists.

2. Teachers have full freedom to modify the curriculum in line with the characteristics of the students [9]. Due to the existence of the modified curriculum, teachers will easily attain the target of the curriculum made by the government.

3. Students with special needs have some betterments in their self-respect since they study in normal schools. In general, schools which are special for children with special needs are called Sekolah Luar Biasa $(S L B)$. The parents whose children with special needs study in this kind of schools are inferior.

4. Teachers are skillful in implementing the learning process special for students with special needs who have various backgrounds.

5. Educators have opportunities in digging out, developing and applying various new ideas through communication due to the existence of the curriculum and learning system which is in line with the students' needs

\section{Weaknesses}

Weakness is a condition becoming the obstacles of the application of inclusive education in Indonesia. The weaknesses are as follows:

1. Not all schools accept children with special needs, except the central or main schools which are assigned 
to be the implementers of inclusive education. It is because not all schools possess supporting teachers, facilities and specific accompaniment for children with special needs.

2. Not all characteristics of children with special needs may be accepted in inclusive schools, but it is in accordance with certain characteristics because it is the children with special needs under the "moderate" type who can be accepted because they will be able to socialize with normal children.

3. The curriculum for children with special needs has not been standardized yet so that there are still some differences among one school and another dealing with the curriculum standard. As a result, teachers should modify the regular curriculum and this may make the curriculum not attain the target since the type of children with special needs is different between one and another so no single curriculum for all exists.[10]

4. The government has not provided schools accepting inclusive children with sufficient infrastructures and facilities.

\section{Opportunities}

Opportunity is a change possessed to apply inclusive education in Indonesia.

1. The community will feel a pride because their children go to regular schools, instead of the special ones. The parents' self-confidence is lower when their children study in Sekolah Luar Biasa (SLB).

2. Inclusion-based schools highly attracts the community that make them get more students. Children with special needs will be higher in number so that there will be more parents who look for inclusion-based schools.

3. Children will fully be supported so that a closer relationship among the families, the community and the schools will be established. The roles of the parents are very dominant. When parents have children with special needs, they often consult with the school so that the relationship between the family and the school gets closer and closer.

\section{Threats}

Threats that often occur when inclusive-based education is established in Indonesia are as follows:

1. Disharmonized condition happens in the school environment where not all students can accept students with special needs, so that a bullying system gets higher and higher. A special term still exists: the winner is the one who is strong. This still often happens in regular schools where normal students will bully the students with special needs.

2. When assisting teachers quit their jobs from the schools, the children with special needs cannot go to schools. The feeling of closeness and difficulty to understand make children with special needs difficult to change the assisting teachers

3. The parents' and community's concerns with the quality of educational services including the inclusive schools improvement. Inclusive schools are said to be in high-quality if they can change children.

From the results of the SWOT analysis, a good and high-quality inclusive education may be applied in Indonesia through the followings:

1. Extensive government regulations in the implementation of inclusive education in Indonesia are formulated. The extensive regulations may make all levels of the implementation of inclusive education centralized instead of being localized/or school regulated.

2. The institutional management of inclusive education should be rearranged, aiming at improving the quality of the inclusive education implementation either conceptually or operationally; therefore its activities may be implemented with educational programs in general [11].

3. Human resources management is improved to be able to provide educators and educational staffs possessing adequate competences in giving services to the children with special needs at schools.

4. Accompaniment of the implementation of inclusive education is given so that the schools implementing inclusive education may be directly accompanied by educators and educational staffs at schools to optimize the inclusive education programs.

5. Facilities and infrastructures are created to give supports to educators and educational staffs in implementing the inclusion-based education, remembering that the the needs for facilities and infrastructures of each child with special needs are not the same.

6. The development of partnership cooperation to get real supports from external parties competent in the implementation of inclusive-based education occurs.

\section{CONCLUSION}

Inclusive education which is the latest development of the model of education for all requires a high-quality education where no discrimination is occurs among students, and the infrastructures and human resources should also be really prepared. Referring to the pedagogical concept, limiting children with special needs from any open and high-quality education will not be inhuman and we even agree with the dehumanization of education.

\section{REFERENCES}

[1] Poernomo, Baby. The implementation of inclusive education in Indonesia: Curret Problems and Challenges. American Internasional Journal of Social Science Vol. 5 No 3 144-150. 2016

[2] Inclusive Education What, Why, And How. Save the children: London. 2016

[3] Sunardi. Kecenderungan Dalam pendidikan Luar Biasa (Trends in Special Education. Dikti: Dekdikbud Jakarta. 1995. 
[4] Law kekeh marthan.. Manajemen pendidikan inklusif. Jakarta: dirjen dikti. 2007.

[5] Deded Koswara. Pendidikan anak berkebutuhan khusus berkesulitan belajar spesifik. Jakarta: pt. Luximo metro. H 14. 2013

[6] Dadan Rachmayana, 2013. Diantara pendidikan luar biasa menuju anak masa depan yang inklusi. Pt. Luxima metro media: jakarta timur Illahi,24.2013.

[7] Sondang P. Siagian.. Manajemen strategik. Pt bumi aksara: Jakarta. 2000.

[9] J. Van swet, j. Wichers-bots, k. Brown, solutionfocused assessment: rethinking labels to support inclusive education. International journal of inclusive education. 15 2011, pp. 909-923. 2011
[10] S. Mcmurray, R. Thompson, inclusion, curriculum and the rights of the child. Journal of research in special educational needs. 16, 634638.2016.

[11] 37-41. http://doi.org/10.1037/a0022390 Tuma, J. M., \& Pratt, J. M. (1982). Clinical child psychology practice and training: A survey. Vdots of Clinical Child \& Adolescent Psychology, 137(August 2012) et al., Three strategies for interdisciplinary teaching: contextualizing, conceptualizing, and problem-centring. Journal of Curriculum Studies. 38, 251-271.2006.

[12] A. Jordan, E. Schwartz, D. McGhie-Richmond, Preparing teachers for inclusive classrooms. Teaching and Teacher Education. 25, 535-542.2009 